University of Nebraska - Lincoln

DigitalCommons@University of Nebraska - Lincoln

Other Publications in Zoonotics and Wildlife

Disease

Wildlife Disease and Zoonotics

1995

\title{
Infections Associated with Bartonella Species in Persons Infected with Human Immunodeficiency Virus
}

\author{
Russell L. Regnery \\ Centers for Disease Control and Prevention \\ James E. Childs \\ james.childs@yale.edu \\ Jane E. Koehler \\ University of CaliforniaA IDS Research Program
}

Follow this and additional works at: https://digitalcommons.unl.edu/zoonoticspub

Part of the Veterinary Infectious Diseases Commons

Regnery, Russell L.; Childs, James E.; and Koehler, Jane E., "Infections Associated with Bartonella Species in Persons Infected with Human Immunodeficiency Virus" (1995). Other Publications in Zoonotics and Wildlife Disease. 54.

https://digitalcommons.unl.edu/zoonoticspub/54

This Article is brought to you for free and open access by the Wildlife Disease and Zoonotics at DigitalCommons@University of Nebraska - Lincoln. It has been accepted for inclusion in Other Publications in Zoonotics and Wildlife Disease by an authorized administrator of DigitalCommons@University of Nebraska Lincoln. 


\title{
Infections Associated with Bartonella Species in Persons Infected with Human Immunodeficiency Virus
}

\author{
Russell L. Regnery, James E. Childs, \\ and Jane E. Koehler
}

From the Viral and Rickettsial Zoonoses Branch, Division of Viral and
Rickettsial Diseases, Centers for Disease Control and Prevention,
Atlanta, Georgia; and the Division of Infectious Diseases, University of
California, San Francisco, California

\begin{abstract}
Two members of the genus Bartonella, Bartonella quintana (formerly Rochalimaea quintana) and Bartonella henselae (formerly Rochalimaea henselae), have recently been recognized as agents of severe or fatal disease in patients infected with human immunodeficiency virus (HIV). The development of infection with $B$. henselae in HIV-infected individuals has been associated with traumatic contact with cats (scratches or bites), and domestic cats have been identified as a major reservoir for this organism. Specific information regarding the transmission of $B$. henselae to humans is not yet available, but common-sense precautions that minimize exposure to cat-associated organisms are appropriate. Preliminary accounts suggest that $B$. quintana infections are more common than $B$. henselae infections among HIV-infected individuals in San Francisco. The source of infection with $B$. quintana and the mechanism of its transmission remain unknown.
\end{abstract}

The four species of the genus Rochalimaea (Rochalimaea quintana, Rochalimaea henselae, Rochalimaea elizabethae, and Rochalimaea vinsonii) were recently shown to be closely related to the sole member of the genus Bartonella (Bartonella bacilliformis) [1]. Because Bartonella was described before Rochalimaea, the former designation takes precedence over the latter. Thus the name Bartonella will be used in this document to describe all five members of the expanded genus. However, in many publications the name Rochalimaea may still be used. Species names remain unchanged; e.g., $R$. henselae is now known as Bartonella henselae.

\section{Background}

The diseases known to be associated with Bartonella species are listed in table 1. Historically, the best-known member of the genus is Bartonella quintana, the bacterium that caused trench fever in World War I [2]. In 1990, DNA sequences closely related to $B$. quintana were identified in the lesions of patients with bacillary angiomatosis (BA) [3], a vascular proliferative disorder that occurs in HIV-infected persons [4]. Independently, a fastidious gram-negative rod was isolated from HIV-infected patients with a relapsing febrile illness [5], and similar bacilli were noted in tissue from patients with an

J.E.K. is a Pew Scholar in the Biomedical Sciences and was supported by the National Institutes of Health (grant no. R29 AI36075) and the University of California AIDS Research Program.

Reprints or correspondence: Dr. Russell Regnery, Viral and Rickettsial Zoonoses Branch, Mailstop G-13, Centers for Disease Control and Prevention, 1600 Clifton Road, Atlanta, Georgia 30333.

Clinical Infectious Diseases 1995;21(Suppl 1):S94-8

(c) 1995 by The University of Chicago. All rights reserved. $1058-4838 / 95 / 2102-0006 \$ 02.00$ unusual hepatic disease known as peliosis hepatis [6]. A novel species, $B$. henselae, was later isolated and fully characterized $[7,8]$. Gene sequences from $B$. henselae were identical to those previously identified in biopsied tissues from patients with BA and peliosis hepatis $[3,7]$. The subsequent isolation of bacteria directly from cutaneous lesions of BA revealed that either $B$. henselae or B. quintana can cause this disease [9]. Over the past decade, since BA was first described by Stoler et al. in New York City [10], the spectrum of bartonella infection in patients with concomitant HIV infection has been expanding; now included are endocarditis $[11,12]$ and angiomatous lesions involving many organs, including the skin, liver, lung, spleen, bone, and brain. (For a summary of the involvement of various organs, see [13].) Although cutaneous BA can be an indolent disease with remissions and exacerbations over many months [4], its systemic symptoms can be debilitating. When bartonella infection remains undiagnosed in patients with HIV infection, it can be fatal [14].

Recently, $B$. henselae was found to be the cause of catscratch disease [15-17] in addition to some cases of BA. The reason for the different host responses to infection with $B$. henselae (granulomatous in the immunocompetent host and vascular proliferative in the immunocompromised host) is unknown. Immunocompetent people with $B$. henselae infection can develop a prolonged febrile and relapsing illness [18] like that seen in HIV-infected patients [5, 7].

Infection with the remaining three Bartonella species has not been reported in HIV-infected patients. Bartonella elizabethae caused severe endocarditis in one immunocompetent patient [19]. No human infections with Bartonella vinsonii have been identified. $B$. bacilliformis, the etiologic agent of bartonellosis, causes biphasic illness: the acute febrile phase is known as Oroya fever, and the chronic phase with cutaneous vascular lesions is known as verruga peruana [20]. These cutaneous 
Table 1. Diseases with well-documented associations with Bartonella species.

\begin{tabular}{ll}
\hline Immune status, disease & \multicolumn{1}{c}{ Causative species of Bartonella } \\
\hline Competent & \\
Cat-scratch disease & B. henselae \\
Trench fever & B. quintana \\
Bartonellosis & B. bacilliformis \\
Endocarditis & B. henselae, B. quintana, B. elizabethae \\
Compromised & \\
Bacillary angiomatosis & B. henselae, B. quintana \\
Relapsing bacteremia with fever & B. henselae, B. quintana \\
Endocarditis & B. henselae, B. quintana \\
\hline
\end{tabular}

eruptions are sometimes indistinguishable from those of BA; however, infection with $B$. bacilliformis has been reported only in the Andes Mountains of South America [20].

Numerous reports in the literature describe good clinical responses of immunocompromised patients with $\mathrm{BA}$ or peliosis hepatis to treatment with erythromycin or doxycycline. In the experience of one of the authors (J.E.K.), erythromycin, doxycycline, tetracycline, and minocycline have been successful in the treatment of these conditions (table 2) [13]. Rifampin and gentamicin appear to have some clinical efficacy; although there is insufficient evidence to recommend the use of either agent alone, these drugs may be of value when combined with a first-line agent for the treatment of immunocompromised patients with severe Bartonella-associated disease (e.g., osteomyelitis, peliosis hepatis, or endocarditis). There are conflicting reports regarding the response of BA lesions in immunocompromised patients to treatment with quinolones [13].

The optimal duration of treatment for immunocompromised individuals is unknown, but patients with cutaneous BA should receive an appropriate antibiotic for at least 2 or 3 months; patients with more severe disease (osteomyelitis, peliosis hepatis) should receive a minimum of 3 or 4 months of antibiotic therapy. Most patients treated with tetracycline or erythromycin for 4 months do not have a relapse. However, like salmonellosis and various other bacterial infections, bartonella infection can relapse in some cases even after prolonged therapy with erythromycin [9]. Immunocompromised patients with bartonella infection should be followed closely if antibiotic treatment is stopped after 4 months; if a relapse occurs, these individuals should be treated indefinitely with suppressive antibiotics.

Although the clinical response to antibiotics is dramatic among immunocompromised patients with bartonella infection, the response of people with intact immune systems and catscratch disease or relapsing bacteremia remains equivocal [18, 21]. The curious influence of the host's immune status on apparent antibiotic efficacy may be related to different manifestations of the syndromes. Cat-scratch disease is clinically defined by swollen lymph nodes and granulomatous lesionssigns that cannot develop in severely immunocompromised hosts and that cannot be expected to regress as long as antigen is present. It is possible that persons with intact immune systems, unlike severely immunocompromised patients, sequester viable or antigenically active Bartonella within either cells or immune-mediated tissue complexes (e.g., granulomas).

\section{Incidence}

Preliminary estimates of the prevalence of antibody to Bartonella among apparently healthy humans range from $4 \%$ to $6 \%[15,22]$. Cat-scratch disease is clinically diagnosed in an estimated 22,000 persons each year in the United States [23]. The incidence of Bartonella-associated disease among HIVinfected persons is unknown. These infections may go unrecognized in the majority of cases, and the interval between infection and the diagnosis of BA can cover months or even a year [9]. In addition, disease in immunocompromised persons may represent reactivation of infection rather than primary infection: low-titer antibodies to Bartonella have been documented in banked sera obtained from HIV-infected people before the diagnosis of $\mathrm{BA}$, with increased titers at the time of diagnosis [24].

Bartonella infections in HIV-infected people often are not recognized for a number of reasons. First, cutaneous BA lesions can be clinically indistinguishable from Kaposi's sarcoma [25]; in these cases, BA can be distinguished only by biopsy with histopathologic examination. A characteristic vascular proliferation with a mixed inflammatory infiltrate is evident upon hematoxylin and eosin staining of biopsied BA tissue, and bacillary organisms can be demonstrated by Warthin-Starry staining [4]. Second, hepatic disease caused by Bartonella specieseven the relatively dramatic form, peliosis hepatis - can be indistinguishable from other infectious or malignant conditions that cause hypodense lesions demonstrable by abdominal CT (e.g., lymphoma, Kaposi's sarcoma, extrapulmonary pneumocystosis, and bacterial and fungal abscesses). Third, clinicians evaluating HIV-infected patients may fail to consider Barto-

Table 2. Clinical response of HIV-infected individuals with bacillary angiomatosis or peliosis hepatis to antibiotic treatment (San Francisco General Hospital/University of California at San Francisco, 1987-1995).

\begin{tabular}{llll}
\hline Definite & Possible & Inconclusive & None \\
\hline Erythromycin & Gentamicin & Ciprofloxacin & Penicillin \\
Doxycycline & Rifampin & Ceftriaxone & $\begin{array}{c}\text { Penicillin } \\
\text { derivatives }\end{array}$ \\
Tetracycline & & Trimethoprim/ & $\begin{array}{c}\text { First generation } \\
\text { cephalosporins }\end{array}$ \\
Minocycline & & sulfamethoxazole & \\
\hline
\end{tabular}

NOTE. Table is adapted with permission from [13]. 
Table 3. Manifestations of bartonella infections in HIV-infected patients.

\begin{tabular}{ll}
\hline Organ & \multicolumn{1}{c}{ Manifestation } \\
\hline $\begin{array}{l}\text { Skin (bacillary } \\
\text { angiomatosis) }\end{array}$ & $\begin{array}{c}\text { Diverse presentations, including lesions } \\
\text { resembling Kaposi's sarcoma, angiomatous } \\
\text { nodules, friable vascular lesions, red papules, } \\
\text { pedunculated lesions, and deep subcutaneous } \\
\text { masses } \\
\text { Bone }\end{array}$ \\
$\begin{array}{l}\text { Extremely painful osteolysis, lytic lesions on } \\
\text { radiography (positive technetium scan) }\end{array}$ \\
$\begin{array}{l}\text { Enlargement } \\
\text { Blood }\end{array}$ \\
$\begin{array}{l}\text { Valvular vegetation, fever, weight loss } \\
\text { peliosis }\end{array}$ \\
$\begin{array}{l}\text { Fever, thrombosis } \\
\text { Hypodense lesions, hepatosplenomegaly on CT, } \\
\text { elevated values in liver function tests (e.g., } \\
\text { alkaline phosphatase), pancytopenia, } \\
\text { thrombocytopenia }\end{array}$ \\
Involvement of brain, gastrointestinal tract, \\
lungs, etc.
\end{tabular}

NOTE. Table is adapted from [26].

nella in the differential diagnosis of a febrile illness in the absence of cutaneous lesions or peliosis hepatis (table 3) [26].

Finally, culture of Bartonella species is difficult, requiring special media and techniques. This situation compounds the problems encountered in the diagnosis of isolated bartonella bacteremia, even when this diagnosis is considered. A genusspecific IgG indirect fluorescent antibody (IFA) test recently developed at the Centers for Disease Control and Prevention (CDC) is both sensitive and specific for the confirmation of a diagnosis of cat-scratch disease $[15,22]$. Patients with catscratch disease typically have elevated titers of Bartonellaspecific IgG antibody at the time of their presentation to the health care practitioner; titers appear to diminish within a year of the original diagnosis [22]. The diagnosis of cat-scratch disease by IFA test has correlated well $(98 \%$; 55 of 56 cases) with clinical diagnosis and skin testing [27], and the specificity of the IFA test is $\sim 95 \%[15,22]$. An IgM ELISA has also shown relatively good sensitivity ( $95 \% ; 53$ of 56 cases) in studies of patients with cat-scratch disease diagnosed by skin testing; however, the specificity of the ELISA was only $77 \%$ (43 of 56 cases) [27]. Preliminary results suggest that the IFA test shows promise in the laboratory confirmation of bartonella infections in HIV-infected patients [24]. Improved diagnostic tests will result in more accurate assessment of the true incidence of bartonella infection in this population and may facilitate appropriate treatment. Reagents for IFA testing for Bartonella are currently available to regional and state health laboratories from the CDC. Additional diagnostic techniques for the serological testing of patients (including commercial tests) are being developed. However, before their widespread use as diagnostic tools, additional blinded, side-by-side evalua- tions of specificity and sensitivity for the various Bartonellaassociated syndromes are necessary.

\section{Source of Infection and Risk Factors}

Numerous anecdotal reports have described exposure to and contact with cats before the development of BA in immunocompromised patients [13]. A case-control analysis found that recent contact with cats was the only environmental risk factor associated with BA [28]. Patients with BA-but not control patients - were statistically more likely to have been licked, scratched, or bitten by a cat before developing this illness. The amount of time spent with a cat was associated with the degree of risk. As had previously been documented in studies of catscratch disease in HIV-uninfected populations [22, 29], ownership of kittens or young cats (i.e., those $<1$ year old) posed a particularly high risk to HIV-infected persons for acquiring B. henselae-associated disease [28].

It has recently been shown that the domestic cat provides a major reservoir from which HIV-infected patients apparently acquire $B$. henselae infection. Seven pet cats belonging to four patients with confirmed BA due to $B$. henselae had this organism isolated from the bloodstream, as did 25 (41\%) of 61 randomly sampled cats in San Francisco [30]. Seroepidemiological studies indicate that $B$. henselae infection of domestic cats is also common in other regions of the United States, with a prevalence of Bartonella-specific antibodies ranging from $14 \%$ to $50 \%$ [22, 31]. An estimated one-third of all households in the United States include a cat [32], and cats may be persistently bacteremic for prolonged periods without obvious signs of illness $[30,33]$. Thus, pet cats pose a real but probably small risk of $B$. henselae infection to HIV-infected owners [34].

Exposure to kittens with fleas has been reported to be a risk factor for cat-scratch disease. Thus, it has been suggested that arthropod vectors transmit $B$. henselae among felines and/or between felines and humans, although a cat scratch or bite has been more strongly associated with acquisition of the disease [22]. Viable $B$. henselae bacilli have been isolated from fleas from cats [30], but the fleas' ability to transmit $B$. henselae has not been established. Ticks also have been suggested as possible vectors of $B$. henselae $[18,22]$.

Early in the investigation of Bartonella-associated diseases, the human body louse (Pediculus humanus) was identified as a vector of human-to-human transmission of $B$. quintana [2]. However, virtually nothing is known about possible arthropod vectors or possible alternative vertebrate reservoirs of B. quintana infections today. B. bacilliformis can be transmitted by the sandfly (genus Phlebotomus) within its naturally occurring geographic range [20]. Neither nonhuman reservoirs nor possible arthropod vectors of $B$. elizabethae are known. Because infections with $B$. bacilliformis and $B$. quintana can be arthropod-borne, it is plausible that other members of the genus (e.g., B. henselae) also have arthropod vectors. 
The risk of developing relatively severe disease due to Bartonella species appears to increase as the $\mathrm{CD}^{+}$cell count decreases. In a recent review, the mean $\mathrm{CD}^{+}$cell count of 15 HIV-infected patients with Bartonella-associated disease was $57 / \mathrm{mm}^{3}$ [13]. In a case-control study of 42 patients with bartonella infection, patients with BA were statistically more likely than controls to have a CD4 ${ }^{+}$cell count of $<200 / \mathrm{mm}^{3}$ [35].

\section{Prevention}

Physicians should recognize the potential psychological value of companion animals for seriously ill persons. However, immunocompromised persons who have no prior emotional attachment to a cat and who are concerned about the risk of $B$. henselae infection should consider alternative species for companionship. Of course, the potential for zoonotic disease associated with nonfeline companion-animal species also must be considered [34].

Because data are not yet available on the degree of risk to humans for $B$. henselae infection related to contact with cats or on the mode of $B$. henselae transmission from one cat to another or from cats to humans, specific recommendations for prevention are currently limited to common-sense precautions $[34,36]$. Adult cats pose a lesser risk than do cats $<1$ year old. Severely immunocompromised persons should avoid rough play with cats that might result in scratches or bites and should not allow a cat to lick open cuts or wounds. Contamination of broken skin with cat secretions should be avoided, and cat-associated wounds should be washed immediately with soap and water. Control of fleas is appropriate.

Recommendations regarding the prevention of $B$. quintana infection are presently limited to the avoidance of exposure to the human body louse.

\section{Research Priorities}

Bartonella-associated disease among HIV-infected persons has been described only recently, but it is already evident that treatment and preventive efforts can be beneficial. The incidence of Bartonella-associated disease must be established, and the spectrum of disease (including syndromes currently undiagnosed) must be more completely elucidated. Economical, rapid, sensitive, and specific methods for laboratory diagnosis need to be further developed and disseminated to local health care centers. The timing, type, and duration of antibiotic prophylaxis for initial or reactivated bartonella infection in HIV-infected persons (especially those who are seropositive for Bartonella) should be considered. The development of microbial resistance is a theoretical possibility during prolonged antimicrobial therapy.

More complete analyses of risk factors for infections due to $B$. henselae and $B$. quintana must be undertaken. The route by which cats become infected with $B$. henselae and the way in which this organism persists in and is subsequently transmitted by these animals should be established. The potential for the elimination of feline infections due to $B$. henselae by antibiotic treatment and for the prevention of reinfection must be studied. A feline vaccine designed to prevent $B$. henselae infection should be developed, with the interruption of transmission to HIV-infected pet owners as the ultimate goal. The possible role of arthropod vectors in the transmission of $B$. henselae and $B$. quintana needs to be clarified.

\section{References}

1. Brenner DJ, O'Connor SP, Winkler HH, Steigerwalt AG. Proposals to unify the genera Bartonella and Rochalimaea, with descriptions of Bartonella quintana comb. nov., Bartonella vinsonii comb. nov., Bartonella henselae comb. nov., and Bartonella elizabethae comb. nov., and to remove the family Bartonellaceae from the order Rickettsiales. Int $\mathbf{J}$ Syst Bacteriol 1993;43:777-86.

2. Strong RP, ed. Trench fever: report of commission, Medical Research Committee, American Red Cross. Oxford: Oxford University Press, 1918:40-60

3. Relman DA, Loutit JS, Schmidt TM, Falkow S, Tompkins LS. The agent of bacillary angiomatosis: an approach to the identification of uncultured pathogens. N Engl J Med 1990;323:1573-80.

4. LeBoit PE, Berger TG, Egbert BM, et al. Bacillary angiomatosis: the histopathology and differential diagnosis of a pseudoneoplastic infection in patients with human immunodeficiency virus disease. Am J Surg Pathol 1989; 13:909-20.

5. Slater LN, Welch DF, Hensel D, Coody DW. A newly recognized fastidious gram-negative pathogen as a cause of fever and bacteremia. N Engl J Med 1990;323:1587-93.

6. Perkocha LA, Geaghan SM, Yen TSB, et al. Clinical and pathological features of bacillary peliosis hepatis in association with human immunodeficiency virus infection. N Engl J Med 1990;323:1581-6.

7. Regnery RL, Anderson BE, Clarridge JE III, Rodriguez-Barradas MC, Jones DC, Carr JH. Characterization of a novel Rochalimaea species, $R$. henselae, sp. nov., isolated from blood of a febrile, HIV-positive patient. J Clin Microbiol 1992;30:265-74.

8. Welch DF, Pickett DA, Slater LN, Steigerwalt AG, Brenner DJ. Rochalimaea henselae sp. nov., a cause of septicemia, bacillary angiomatosis, and parenchymal bacillary peliosis. J Clin Microbiol 1992;30:275-80.

9. Koehler JE, Quinn FD, Berger TG, LeBoit PE, Tappero JW. Isolation of Rochalimaea species from cutaneous and osseous lesions of bacillary angiomatosis. N Engl J Med 1992;327:1625-31.

10. Stoler MH, Bonfiglio TA, Steigbigel RT, Pereira M. An atypical subcutaneous infection associated with acquired immune deficiency syndrome. Am J Clin Pathol 1983;80:714-8.

11. Spach DH, Callis KP, Pauw DS, et al. Endocarditis caused by Rochalimaea quintana in a patient infected with human immunodeficiency virus. J Clin Microbiol 1993;31:692-4.

12. Hadfield TL, Warren R, Kass M, Brun E, Levy C. Endocarditis caused by Rochalimaea henselae. Hum Pathol 1993;24:1140-1.

13. Koehler JE, Tappero JW. Bacillary angiomatosis and bacillary peliosis in patients infected with human immunodeficiency virus. Clin Infect Dis 1993; 17:612-24.

14. Cockerell CJ, Whitlow MA, Webster GF, Friedman-Klen AE. Epithelioid angiomatosis: a distinct vascular disorder in patients with the acquired immunodeficiency syndrome or AIDS-related complex. Lancet 1987; $2: 654-6$.

15. Regnery RL, Olson JG, Perkins BA, Bibb W. Serological response to "Rochalimaea henselae" antigen in suspected cat-scratch disease. Lancet $1992 ; 339: 1443-5$. 
16. Dolan MJ, Wong MT, Regnery RL, et al. Syndrome of Rochalimaea henselae adenitis suggesting cat scratch disease. Ann Intern Med 1993; 118:331-6.

17. Schmidt MJ, Robinson LE, Regnery RL, Olson JG, Childs JE. Encephalopathy and liver lesions in patients with cat-scratch disease [session 127]. In: Program and abstracts of the 33rd Interscience Conference on Antimicrobial Agents and Chemotherapy (New Orleans). Washington, DC: American Society for Microbiology, 1993.

18. Lucey D, Dolan MJ, Moss CW, et al. Relapsing illness due to Rochalimaea henselae in immunocompetent hosts: implication for therapy and new epidemiological associations. Clin Infect Dis 1992;14:683-8.

19. Daly JS, Worthington MG, Brenner DJ, et al. Rochalimaea elizabethae sp. nov. isolated from a patient with endocarditis. J Clin Microbiol 1993; 31:872-81.

20. Schultz MG. A history of bartonellosis (Carrion's disease). Am J Trop Med Hyg 1968; 17:503-15.

21. Margileth AM. Antibiotic therapy for cat-scratch disease: clinical study of therapeutic outcome in 268 patients and a review of the literature. Pediatr Infect Dis J 1992;11:474-8.

22. Zangwill KM, Hamilton DH, Perkins BA, et al. Cat scratch disease in Connecticut: epidemiology, risk factors, and evaluation of a new diagnostic test. N Engl J Med 1993;329:8-13.

23. Jackson LA, Perkins BA, Wenger JD. Cat scratch disease in the United States: an analysis of three national databases. Am J Public Health 1993; 83:1707-11.

24. Tappero J, Regnery R, Koehler J, Olson J. Detection of serologic response to Rochalimaea henselae in patients with bacillary angiomatosis (BA) by immunofluorescent antibody (IFA) testing [abstract no 674]. In: Program and abstracts of the 32nd Interscience Conference on Antimicrobial Agents and Chemotherapy (Anaheim). Washington, DC: American Society for Microbiology, 1992.
25. Berger TG, Tappero JW, Kaymen A, LeBoit PE. Bacillary (epithelioid) angiomatosis and concurrent Kaposi's sarcoma in acquired immunodeficiency syndrome. Arch Dermatol 1989; 125:1543-7.

26. Koehler J. Recurrent bacterial infections: Bartonella. Clinical Care Options for HIV 1995; 1(3):17-18

27. Szelc-Kelly CM, Goral S, Perez-Perez GI, Perkins BA, Regnery RL, Edwards KM. Serologic responses to Bartonella henselae and Afipia felis in patients with cat-scratch disease. Pediatrics 1995 (in press).

28. Tappero JW, Mohle-Boetani J, Koehler JE, et al. The epidemiology of bacillary angiomatosis and bacillary peliosis. JAMA 1993;269:770-5.

29. Carithers HA. Cat-scratch disease: an overview based on a study of 1,200 patients. Am J Dis Child 1985; 139:1124-33.

30. Koehler JE, Glaser CA, Tappero JW. Rochalimaea henselae: a new zoonosis with the domestic cat as reservoir. JAMA 1994;271:531-5.

31. Childs JE, Rooney JA, Cooper JL, Olson JG, Regnery RL. Epidemiology of Rochalimaea infections in Baltimore City cats. J Am Vet Med Assoc 1994; $204: 1775-8$.

32. Wise JK, Yang JJ. Veterinary service market for companion animals, 1992. Part 1: Companion animal ownership and demographics. J Am Vet Med Assoc 1992;201:990-2.

33. Regnery R, Martin M, Olson J. Naturally occurring "Rochalimaea henselae" infection in domestic cat. Lancet 1992;340:557-8.

34. Angulo FJ, Glaser CA, Juranek DD, Lappin MR, Regnery RL. Caring for pets of immunocompromised persons. J Am Vet Med Assoc 1994; $205: 1711-8$

35. Mohle-Boetani J, Reingold A, LeBoit P, Berger T, Wenger J, Tappero J. Bacillary angiomatosis: spectrum of disease and clinical characteristics in $\mathrm{HIV}^{+}$patients [abstract no 372]. In: Program and abstracts of the 32nd Interscience Conference on Antimicrobial Agents and Chemotherapy (Anaheim). Washington, DC: American Society for Microbiology, 1992.

36. Groves MG, Harrington KS. Rochalimaea henselae infections: newly recognized zoonoses transmitted by domestic cats. J Am Vet Med Assoc 1994; $204: 267-71$ 